\title{
HUBUNGAN FREKUENSI BERMAIN BULU TANGKIS DENGAN TEKANAN DARAH PADA ANGGOTA PB UNMUH PONOROGO
}

\author{
Saiful Nurhidayat \\ Prodi S1 Keperawatan Fakultas IImu Kesehatan \\ Universitas Muhammadiyah Ponorogo \\ E-mail : saiful.nurhidayat2@gmail.com
}

\begin{abstract}
Physical activity in addition to dealing with heart rate, will cause an increase in blood pressure (Sulastri et al., 2012). Exercise or physical activity carried out regularly and regularly can turn a stressor into a stimulator. But if physical activity is done irregularly, the stressor will inhibit the homeostatic process in the body. The purpose of this study is to determine the relationship between the frequency of playing badminton and blood pressure in PB UNMUH Ponorogo members. The research will be conducted on PB UNMUH Ponorogo members, a representative sample of 33 respondents taken by Purposive Sampling. Quantitative design with Cross sectional design that studies the frequency of playing badminton and blood pressure. The instrument in this study used a questionnaire and observation sheet. Univariate analysis uses frequency distribution. Gamma Test to find out the relationship between the frequency of playing badminton and blood pressure. The results of the study showed that the majority of PB UNMUH Ponorogo's members of badminton played mostly $(48.5 \%)$ or 16 people twice a week. Blood pressure of $39.4 \%$ or 13 respondents was normal. There is a relationship between the frequency of playing badminton with the incidence of hypertension in members of $P B$ UNMUH Ponorogo with $P=0.020(=0.05)$. The closeness of the value (Value) is 0.452. It is expected that $P B$ UNMUH Ponorogo members can do badminton training regularly and the intensity is adjusted to their respective abilities in order to achieve optimal fitness and avoid hypertension or other heart disease.
\end{abstract}

Keywords: frequency of playing badminton, blood pressure.

Abstrak :Aktivitas fisikselain berhubungan dengan denyut jantung, akan menyebabkan peningkatan tekanan darah(Sulastri et al., 2012).Olahraga atau aktivitas fisik yang dilakukan secara rutin dan teratur dapat mengubah stressor menjadi stimulator. Tetapi jika aktivitas fisik dilakukan dengan tidak teratur maka stressor tersebut akan menghambat proses homeostatis dalam tubuh.Tujuan penelitian ini adalah untuk mengetahui hubungan frekuensi bermain bulutangkis dengan tekanan darah pada anggota PB UNMUH Ponorogo. Penelitian dilakukan pada anggota PB UNMUH Ponorogo,sampel representatif sejumlah 33 responden diambil secara Purposive Sampling. Desainkuantitatif dengan rancanganCross sectionalyang mempelajari frekuensi bermain bulutangkis dan tekanan darah. Instrumen pada penelitian ini menggunakan kuesioner dan lembar observasi. Analisis univariat menggunakan distribusi frekuensi. Uji Gamma untuk mengetahui hubungan frekuensi bermain bulutangkis dengan tekanan darah. Hasil penelitian menunjukkan bahwa frekuensi bermain bulutangkis anggota PB UNMUH Ponorogo sebagian besar $(48,5 \%)$ atau 16 orang sebanyak 2 kali seminggu. Tekanan darah sejumlah $39,4 \%$ atau 13 responden adalah normal. Terdapat hubungan antara frekuensi bermain bulutangkis dengan kejadian hipertensi anggota PB UNMUH Ponorogo dengan $P=0,020(\alpha=0,05)$. Adapun keeratan hubungannya (Value) sebesar -0,452. Diharapkan anggota PB UNMUH Ponorogo dapat melakukan latihan bulutangkis secara teratur dan intensitas disesuaikan dengan kemampuannya masing- masing agar mencapai kebugaran optimal dan terhindar dari penyakit hipertensi ataupun penyakit jantung yang lain.

Kata Kunci : frekuensi bermain bulutangkis, tekanan darah

\section{PENDAHULUAN}

Olahraga merupakan bentuk aktivitas fisik yang dapat mengoptimalkan kebugaran jasmani manusia apabila dilakukan dalam suatu periode waktu tertentu dan dilakukan secara rutin.Latihan olahraga yang dilakukan secara teratur dan terukur dengan intensitas latihan ringan sampai sedang dapat meningkatkan kesehatan, kebugaran tubuh dan kekebalan tubuh (Siti, 2013).Selain berhubungan dengan denyut jantung, aktivitas fisik akan menyebabkan peningkatan tekanan darah (Sulastri et al., 2012).

Di Indonesia bulutangkis merupakan olahraga terpopuler nomer 3 setelah sepak bola dan bola voli (Data Kemenpora, 2014).Di Ponorogo menurut Data PBSI Pemkab. Ponorogo (2017) tercatat ada lebih dari 10 klub bulutangkis, salah satunya adalah PB UNMUH Ponorogo. Anggota dari PB UNMUH Ponorogo tidak hanya mereka yang bekerja di UNMUH saja tetapi juga banyak yang bekerja di luar UNMUH seperti guru, pengusaha, pedagang, 
wiraswasta dan lain-lain. Jumlah anggota sebanyak 50 orang. Jadwal latihan PB UNMUH setiap hari Rabu pagi di gedung Reyog dan hari Jumat pagi di Gedung Bulutangkis Desa Japan Ponorogo. Selain itu ada beberapa anggota latihan di luar jadwal tersebut.

Di Ponorogo sendiri, penelitian yang dilakukan oleh Nurhidayat (2014) mengemukakan bahwa remaja penderita kardiovaskular memiliki aktivitas fisik yang ringan yaitu sebanyak 28 responden (56\%) sedangkan yang memiliki aktivitas sedang yaitu 14 responden (28\%) dan yang memiliki aktivitas fisik berat yaitu 8 responden (16\%). Hal ini berarti pada penderita kardiovaskular lebih banyak melakukan aktivitas fisik ringan. Seseorang melakukan olahraga atau aktivitas fisik maka kebutuhan darah yang mengandung oksigen akan semakin meningkat. Untuk memenuhi kebutuhan ini, jantung akan berkompensasi dengan meningkatkan aliran darahnya. Hal ini juga direspon oleh darah dengan melebarkan diameter pembuluh darah (vasodilatasi) sehingga berdampak pada tekanan darah orang tersebut (Rai, 2012)

Kecenderungan orang-orang saat ini kurang memperhatikan frekuensi dan intensitas mereka dalam melakukan olahraga. Bisa disebabkan karena faktor pekerjaan atau faktor eksternal lainnya. Olahraga atau aktivitas fisik yang dilakukan secara rutin dan teratur dapat mengubah stressor menjadi stimulator. Tetapi jika aktivitas fisik dilakukan dengan tidak teratur maka stressor tersebut akan menghambat proses homeostatis dalam tubuh. Anggota PB UNMUH Ponorogo masih banyak yang melakukan latihan bulutangkis dengan tidak menghiraukan frekuensi latihan yang tepat untuk dirinya sendiri. Hal ini memungkinkan mengalami resiko tinggi untuk mengalami syndrom overtraining dan juga mempengaruhi tekanan darahnya.

Berdasarkan permasalahan diatas peneliti tertarik untuk meneliti hubungan frekuensi latihan bulutangkis dengan tekanan darah pada anggota PB UNMUH Ponorogo.

\section{METODE PENELITIAN}

Penelitian ini merupakan penelitian kuantitatif dengan rancangan cross sectional. Rancangan ini digunakan untuk mempelajari frekuensi bermain bulutangkis dan nilai tekanan darah serta mengkaji hubungan antara variable frekuensi bermain bulutangkis dengan variable kestabilan tekanan darah yang dilakukan secara serentak dalam satu waktu pada anggota PB UNMUH Ponorogo. Lokasi Penelitian dilaksanakan di Gedung
Olah Raga Bulutangkis "REYOG" Jalan Pramuka serta Gedung Bulutangkis Desa Japan Ponorogo. Alasan pemilihan lokasi adalah tempat PB UNMUH melakukan latihan bulutangkis. Populasi penelitian ini adalah seluruh anggota PB UNMUH Ponorogo sejumlah 50 orang. Sampel pada penelitian ini adalah sebagian anggota PB UNMUH Ponorogo. Perhitungan besar sampel pada penelitian ini menggunakan rumus Slovin sejumlah 33 responden.

Pengumpulan data dilakukan dengan menggunakan alat ukur kuesioner. Karakteristik responden terdiri dari 2 item pertanyaan meliputi nama, umur, pendidikan, pekerjaan. Frekuensi bermain bulutangkis diukur berapa latihan perminggu. Lembar observasi digunakan untuk mengukur tekanan darah dengan dikategorikan menjadi tiga tingkatan yaitu 1 : normal jika tekanan darah $<120 / 80 \mathrm{mmHg}$. 2 : prehipertensi jika tekanan darah 120-139/80-89mmHg. 3 : hipertensi jika tekanan darah $\geq 140 / 90 \mathrm{mmHg}$. Peralatan yang digunakan untuk mendukung penelitian adalah, tensi meter, stetoskop. Selain itu juga alat-alat pendukung seperti alkohol, kapas alkohol, tempat kapas alkohol, tissue dan peralatan tulis. Pengumpulan data dengan menggunakan kuesioner dan lembar observasi yang disusun secara terstruktur. Responden diminta menjawab pertanyaan tentang data demografi seperti jenis kelamin, umur, pendidikan dan pekerjaan. Data tentang tekanan darah akan dilakukan pengukuran. Proses Pengumpulan data peneliti dibantu oleh 4 tenaga. Tenaga pengumpul data berasal dari mahasiswa keperawatan prodi S1. Sebelum pengambilan data untuk mempertahankan validitas dan realibilitas akan dilakukan pelatihan dan persamaan persepsi. Analisis data dilakukan secara kuantitatif dan disesuaikan dengan tujuan yang akan dicapai pada penelitian ini, dengan uji statistik yang meliputi 2 macam, analisis univariat digunakan untuk menganalisis secara deskriptif karakteristik masing-masing variabel dengan distribusi frekuensi yang akan ditampilkan dalam bentuk narasi dan tabel. Gambaran karakteristik subjek penelitian yang dihasilkan meliputi usia, pendidikan dan pekerjaan. Variabel yang dianalisis adalah frekuensi bermain bulutangkis dan tekanan darah. Analisis bivariat dilakukan untuk mengetahui hubungan 2 variabel pada kedua kelompok antara variabel bebas dan variabel terikat atau variabel terikat dengan variabel pengganggu. Uji Gamma untuk mengetahui hubungan frekuensi bermain bulutangkis dengan tekanan darah. 


\section{HASIL}

1. Data Umum

Tabel 1 Distribusi Frekuensi Data Umum Responden Berdasarkan Karakteristik Usia Anggota PB UNMUH Ponorogo Pada bulan Juli 2018

\begin{tabular}{cccc}
\hline No. & Usia & $\begin{array}{c}\text { Frekuensi } \\
\text { (orang) }\end{array}$ & $\begin{array}{c}\text { Prosentase } \\
(\%)\end{array}$ \\
\hline 1. & $<40$ & 8 & 24,2 \\
2. & $\geq 40$ & 25 & 75,8 \\
\hline & Jumlah & 33 & 100 \\
\hline
\end{tabular}

Dari tabel 1.dapat diketahui bahwa sebagian besar $(75,8 \%)$ atau 25 responden berusia $\geq 40$ tahun. Sedangkan sebagian kecil $(24,2 \%)$ atau 8 responden berusia $<40$ tahun.

Tabel 2 Distribusi Frekuensi Data Umum Responden Berdasarkan Karakteristik Pendidikan Anggota PB UNMUH Ponorogo Pada bulan Juli 2018

\begin{tabular}{lccc}
\hline No. & Pendidikan & $\begin{array}{c}\text { Frekuensi } \\
\text { (orang) }\end{array}$ & $\begin{array}{c}\text { Prosentase } \\
(\%)\end{array}$ \\
\hline 1. & SMA & 7 & 21,2 \\
2. & S1 & 9 & 27,3 \\
3. & S2 & 13 & 39,4 \\
4. & S3 & 4 & 12,1 \\
\hline & Jumlah & 33 & 100 \\
\hline
\end{tabular}

Dari tabel 2 dapat diketahui bahwa jumlah terbesar (39,4\%) atau 13 responden berpendidikan S2. Sedangkan jumlah terkecil $(12,1 \%)$ atau 4 responden berpendidikan S3.

Tabel 3 Distribusi Frekuensi Data Umum Responden Berdasarkan Karakteristik Pekerjaan Anggota PB UNMUH Ponorogo Pada bulan Juli 2018

\begin{tabular}{lccc}
\hline No. & Pekerjaan & $\begin{array}{c}\text { Frekuensi } \\
\text { (orang) }\end{array}$ & $\begin{array}{c}\text { Prosentase } \\
(\%)\end{array}$ \\
\hline 1. & Karyawan & 6 & 18,2 \\
2. & Swasta & 4 & 12,1 \\
3. & Guru & 4 & 12,1 \\
4. & Wiraswasta & 4 & 12,1 \\
5. & Dosen & 15 & 45,5 \\
\hline & Jumlah & 33 & 100 \\
\hline
\end{tabular}

Dari tabel 3 dapat diketahui bahwa jumlah terbesar (45,5\%) atau 15 responden adalah sebagai Dosen. Sedangkan jumlah terkecil (12,1\%) atau 4 responden adalah wiraswasta, guru dan swasta.

\section{Data Khusus}

A. Frekuensi Bermain Bulutangkis Anggota PB UNMUH Ponorogo

Tabel 4 Distribusi Frekuensi Data Khusus Responden Berdasarkan Frekuensi Bermain Bulutangkis Anggota PB UNMUH Ponorogo Pada bulan Juli 2018

\begin{tabular}{cccc}
\hline No. & $\begin{array}{c}\text { Frekuensi } \\
\text { Bermain/mgg }\end{array}$ & $\begin{array}{c}\text { Frekuensi } \\
\text { (orang) }\end{array}$ & $\begin{array}{c}\text { Prosentase } \\
(\%)\end{array}$ \\
\hline 1. & 1 kali & 9 & 27,3 \\
2. & 2 kali & 16 & 48,5 \\
3. & 3 kali & 6 & 18,2 \\
4. & $>3$ kali & 2 & 6 \\
\hline & Jumlah & 33 & 100 \\
\hline
\end{tabular}


Dari tabel 4 dapat diketahui sebagian besar (48,5\%) atau 16 responden frekuensi bermain bulutangkis 2 kali per minggu, sedangkan $6 \%$ atau 2 responden frekuensi bermain bulutangkis $>3$ kali per minggu.

B. Kejadian Hipertensi Anggota PB UNMUH Ponorogo

Tabel 5 Distribusi Frekuensi Data Khusus Responden Berdasarkan Kejadian HipertensiAnggota PB UNMUH Ponorogo Pada bulan Juli 2018

\begin{tabular}{lccc}
\hline No. & Kejadian Hipertensi & $\begin{array}{c}\text { Frekuensi } \\
\text { (orang) }\end{array}$ & $\begin{array}{c}\text { Prosentase } \\
(\%)\end{array}$ \\
\hline 1. & Normal & 13 & 39,4 \\
2. & Pre Hipertensi & 11 & 33,3 \\
3. & Hipertensi & 9 & 27,3 \\
\hline & Jumlah & 33 & 100 \\
\hline
\end{tabular}

Dari tabel 5 dapat diketahui hampir setengah $(39,4 \%)$ atau 13 responden tekanan darah normal, sedangkan $27,3 \%$ atau 9 responden mengalami hipertensi.

C. Hubungan Frekuensi Bermain Bulutangkis dengan Kejadian Hipertensi Anggota PB UNMUH Ponorogo

Tabel 6 Hubungan Frekuensi Bermain Bulutangkis dengan Kejadian Hipertensi Anggota PB UNMUH Ponorogo Pada bulan Juli 2018

Symmetric Measures

\begin{tabular}{|lc|r|r|r|r|}
\hline & & Value & $\begin{array}{c}\text { Asymp. Std. } \\
\text { Error }^{\mathrm{a}}\end{array}$ & $\begin{array}{c}\text { Approx. } \\
\mathrm{T} \mathrm{b}\end{array}$ & $\begin{array}{c}\text { Approx. } \\
\text { Sig. }\end{array}$ \\
\hline Ordinal by Ordinal & Kendall's tau-b & -.318 & .135 & -2.334 & .020 \\
N of Valid Cases & Gamma & -.452 & .189 & -2.334 & .020 \\
\hline
\end{tabular}

a. Not assuming the null hypothesis.

b. Using the asymptotic standard error assuming the null hypothesis.

Dari tabel 6 dapat diketahui bahwa berdasarkan analisis menggunakan Gamma didapatkan hasil $P=0,020(\alpha=0,05)$. Hasil ini berarti bahwa Terdapat Hubungan antara Frekuensi Bermain Bulutangkis dengan Kejadian Hipertensi Anggota PB UNMUH Ponorogo.

\section{PEMBAHASAN}

Hasil pengumpulan data melalui lembar isian yang telah ditabulasi kemudian diinterpretasikan dan dianalisa sesuai variabel yang diteliti. Maka berikut akan disajikan pembahasan mengenai variabel tersebut. Berdasarkan Dari tabel 4.4 dapat diketahui sebagian besar $(48,5 \%)$ atau 16 responden frekuensi bermain bulutangkis 2 kali per minggu, sedangkan $6 \%$ atau 2 responden frekuensi bermain bulutangkis $>3$ kali per minggu. Dari tabel 4.5 dapat diketahui hampir setengah $(39,4 \%)$ atau 13 responden tekanan darah normal, sedangkan $27,3 \%$ atau 9 responden mengalami hipertensi. Dari tabel 4.6 dapat diketahui bahwa berdasarkan analisis menggunakan Gamma didapatkan hasil $P=0,020(\alpha=0,05)$. Hasil ini berarti bahwa Terdapat Hubungan antara Frekuensi Bermain
Adapun keeratan hubungannya (Value) sebesar $-0,452$ artinya mempunyai keeratan hubungan ringan. Tanda Negatif menunjukkan makna kebalikan antara dua variabel artinya semakin sedikit frekuensi bermain bulutangkis maka semakin besar risiko kejadian hipertensi.

Bulutangkis dengan Kejadian Hipertensi Anggota PB UNMUH Ponorogo. Adapun keeratan hubungannya (Value) sebesar $-0,452$ artinya mempunyai keeratan hubungan ringan. Tanda Negatif menunjukkan makna kebalikan antara dua variabel artinya semakin sedikit frekuensi bermain bulutangkis maka semakin besar risiko kejadian hipertensi.

Dari hasil penelitian didapatkan hasil bahwa sebagian besar $(48,5 \%)$ atau 16 responden frekuensi bermain bulutangkis 2 kali per minggu, sedangkan $6 \%$ atau 2 responden frekuensi bermain bulutangkis $>3$ kali per minggu. Latihan bulutangkis yang sudah dilakukan secara rutin dengan frekuensi $2-3 x$ seminggu dengan durasi antara 20-60 menit akan berpengaruh terhadap kualitas sistem kardiovaskuler. Respon adaptasi kardiovaskuler pada pemain bulutangkis yang rutin menjalani latihan cenderung memiliki 
denyut jantung yang lebih rendah daripada yang tidak rutin. Meningkatnya efisiensi jantung, mengakibatkan aliran darah yang mencapai otot menjadi lebih banyak, dengan adanya persediaan makanan dan $\mathrm{O} 2$ yang memadai, memungkinkan seseorang mencapai hasil yang lebih tinggi. (Giam dalam Alim, 2012).

Dalam beberapa jenis olahraga individu maupun beregu akan terdapat gerakan-gerakan / aktivitas seperti meloncat, mengoper, melempar, menendang bola, memukul bola atau juga mengejar bola dengan cepat yang bersifat anaerobik. Oleh sebab itu maka beberapa cabang olahraga seperti sepakbola, bola basket, bulutangkis atau juga tenis lapangan disebutkan merupakan kegiatan olahraga dengan kombinasi antara aktivitas aerobik dan anaerobik (Hernawati, 2008).

Pada dasarnya aktivitas fisik dibagi menjadi aktivitas aerobik dan anaerobik. Aktivitas aerobik merupakan aktivitas yang membutuhkan ketersediaan oksigen yang digunakan untuk membantu proses pembakaran sumber energi. Aktivitas ini biasanya merupakan aktivitas olahraga dengan intensitas rendah-sedang yang dapat dilakukan secara kontinu dalam waktu yang cukup lama. Sedangkan Aktivitas anaerobik merupakan aktivitas dengan intensitas tinggi yang membutuhkan energi secara cepat dalam waktu yang singkat akan tetapi tidak dapat dilakukan secara kontinu untuk durasi waktu yang lama. Aktivitas ini biasanya juga akan membutuhkan interval istirahat agar ATP dapat diregenerasi sehingga dapat melanjutkan kegiatannya kembali. (Hernawati, 2008).

Bermain bulutangkis dengan frekuensi 2-3x seminggu selama durasi 20-30 menit dapat dilakukan untuk menjaga kebugaran tubuh yang meliputi tekanan darah dan sistem karidorespirasi (Syamsir, 2015).Menurut Stephen et al, di United Kingdom (2016), 13 responden yang melakukan latihan bulutangkis selama 8 minggu mengalami penurunan denyut jantung dengan rata-rata 10-15x/menit. Diperkuat dengan penelitian yang dilakukan oleh Palar et al, (2015) bahwa berolahraga aerobik $3-5 x$ setiap minggu, dengan intensitas latihan sub maksimum atau $60-80 \%$ dari denyut jantung maksimal, dan durasi latihan 20-60 menit akan meningkatkan kebugaran fisik manusia. Menurut peneliti, frekuensi bermain bulutangkis yang terbaik adalah 2-3 kali seminggu selama 20-30 menit tiap bermain satu game. Setelah satu game permainan selesai pemain membutuhkan interval istirahat agar ATP dapat di regenerasi kembali. Setelah cukup istirahat dapat melanjutkan game berikutnya sesuai kemampuan pemain itu sendiriSedangkan frekuensi bermain bulutangkis hanya 1 kali seminggu atau bahkan kurang dari itu, menurut peneliti kurang efektif untuk pelaku olahraga kesehatan karena dapat menyebabkan kekakuan pada otot jantung yang dapat meningkatkan risiko terjadinya penyakit jantung bahkan kematian. Seorang pemain bulutangkis jika ingin menambah kebugaran, melatih ketahanan, menambah kecepatan dan menambah stamina otot diperlukan frekuensi latihan rutin yang bersifat progresif sesuai dengan prinsip-prinsip latihan, tujuan dan kemampuan masing-masing pemain.

Dari tabel 4.1 dapat diketahui bahwa sebagian besar $(75,8 \%)$ atau 25 responden berusia $\geq 40$ tahun. Sedangkan sebagian kecil $(24,2 \%)$ atau 8 responden berusia $<40$ tahun. Semakin bertambahnya usia maka semakin menurun juga daya tahan kardiorespirasi orang tersebut, dengan penurunan $8-10 \%$ perdekade untuk individu yang tidak aktif berolahraga, sedangkan untuk individu yang aktif penurunan tersebut $4-5 \%$ perdekade (Giam dalam Alim, 2012). Menurut peneliti semakin meningkat umur seseorang maka semakin menurun denyut nadi maksimumnya dan daya tahan kardiorespirasinya sehingga pada saat latihan kemungkinan terjadi overtraining.

Dari tabel 4.5 dapat diketahui hampir setengah $(39,4 \%)$ atau 13 responden tekanan darah normal, sedangkan $27,3 \%$ atau 9 responden mengalami hipertensi. Berdasarkan penelitian Nurhidayat (2014) disebutkan bahwa kurangnya aktifitas fisik (aktifitas buruk) merupakan faktor risiko paling dominan penyakit kardiovaskuler yang terjadi pada siswa di Ponorogo. Dari 164 responden yang aktifitas fisik buruk, 71 responden (43,3\%) mengalami penyakit kardiovaskuler (hipertensi). Berdasarkan hasil analisis bivariat terdapat hubungan antara aktifitas fisik yang buruk dengan kejadian penyakit kardiovaskuler (hipertensi) pada siswa $(p=0,002)$ dengan nilai keeratan hubungan 2,121. Hal ini juga didukung hasil analisis regresi logistic didapatkan hasil bahwa aktifitas fisik yang buruk beresiko 2 kali lipat menyebabkan penyakit kardiovaskuler.

Aktivitas fisik pada tingkatan tertentu sangat diperlukan guna menjaga agar mekanisme tekanan darah dapat berjalan sebagaimana mestinya. Pembuluh darah yang kecil dapat mulai tertutup karena kurangnya aktivitas fisik seseorang sehingga bentuknya mengecil. Aktifitas dapat meningkatkan pengeluaran tenaga dengan meningkatkan laju metabolisme, mempercepat mobilisasi simpanan lemak. Kekurangan aktifitas fisik merupakan faktor resiko penyakit kardiovaskuler. Olahraga yang teratur 
berperan penting dalam mencegah penyakit jantung dan pembuluh darah. Olahraga dapat mengontrol kolestrol darah, diabetes, dan obesitas, juga mengontrol tekanan darah (Kusmana, 2006).

Aktivitas fisik/olahraga teratur dapat menurunkan tahanan perifer sehingga dapat menurunkan tekanan darah. Terjadinya peningkatan tekanan darah cenderung berbeda, tergantung dari jenis latihan yang dilakukan. Pada olahraga yang dinamik seperti berlari atau bersepeda output jantung meningkat untuk mempertahankan pasokan darah dan oksigen ke dalam otot yang sedang bekerja. Semakin besar output jantung, semakin tinggi pula tekanan sistoliknya. Peningkatan tekanan sistolik ini cenderung lebih besar daripada pningkatan tekanan diastolik. Pada latihan yang berat mendadak, menjadi peningkatan tekanan darah yang besar. Namun latihan stabil pada orang yang bugar hanya akan menyebabkan peningkatan tekanan darah sedang setelah latihan, tekanan darah menurun di bawah tingkat semula dan dapat bertahan sampai satu jam atau lebih. Yang terdapat bukti bahwa lathan secara teratur dapat menyebabkan penurunan tekanan darah yang berarti.Latihan olahraga sebaiknya dlakukan secara teratur, sehingga tingkat kebugaran dapat dipertahankan dengan mudah.Olahraga aerobik secara teratur tiga atau empat kali seminggu dengan lama 30-45 menit bisa membantu mengurangi resiko hipertensi dan penyakt kardiovaskuler. Orang yang memilki resiko terkena hipertensi 20-25\% lebih tnggi dibandingkan dengan mereka yang aktif. Jika tekanan darah kita tinggi aktivitas fisik yang teratur dapat mengurangi tekanan darah(Agustina, S. 2011).

Dari tabel 4.6 dapat diketahui bahwa berdasarkan analisis menggunakan Gamma didapatkan hasil $P=0,020(\alpha=0,05)$. Hasil ini berarti bahwa Terdapat Hubungan antara Frekuensi Bermain Bulutangkis dengan Kejadian Hipertensi Anggota PB UNMUH Ponorogo. Adapun keeratan hubungannya (Value) sebesar -0,452 artinya mempunyai keeratan hubungan ringan. Tanda Negatif menunjukkan makna kebalikan antara dua variabel artinya semakin sedikit frekuensi bermain bulutangkis maka semakin besar risiko kejadian hipertensi.

Respon adaptasi kardivaskuler pada manusia akan merangsang pusat otak, dan apabila latihan diteruskan akan memberikan signal mekanisme umpan balik pada kardiovaskuler center di batang otak, sehingga menimbulkan perubahan-perubahan berupa penurunan tahanan vaskuler, dan peningkatan cardiac output untuk meningkatkan ambilan oksigen yang pada akhirnya akan meningkatkan tekanan arteri rerata. Menurut peneliti, kenaikan tekanan arteri rerata yang terjadi pada pemain bulutangkis ini merupakan kompensasi tubuh untuk memenuhi kebutuhan oksigen yang diperlukan sewaktu latihan agar proses metabolisme tidak terhambat (Kadir, 2010).

Penelitian Syamsir (2015) menyebutkan bahwa bermain bulutangkis dengan frekuensi 2-3x seminggu dan berdurasi 20-30 menit dapat dilakukan untuk menjaga kebugaran tubuh (kapasitas vital paru, tekanan darah dan kadar hemoglobin). Penelitian lain dari Stephen et al (2016), menyebutkan bahwa 12 dari 13 peserta yang melakukan aktivitas fisik bermain bulutangkis selama 8 minggu mengalami penurunan tekanan darah $8 \mathrm{mmHg}$ untuk yang sistolik dan $6 \mathrm{mmHg}$ untuk yang diastolik. Hal ini disebabkan karena pada pemain bulutangkis yang sudah terlatih atau yang sudah lama menjalani latihan bulutangkis akan terjadi peningkatan aldosterone dan hormone $A D H$ yang menyebabkan retensi cairan oleh ginjal serta adanya peningkatan albumin. Jumlah sel darah merah yang meningkat juga berperan dalam peningkatan volume darah. Perubahan volume darah dan denyut jantung akan sangat mempengaruhi cardiac output yang dihasilkan dan dengan demikian tekanan darah juga akan mengalami perubahan.

Latihan fisik yang dilakukan secara rutin dan terprogram akan menghasilkan perubahan struktural dan fungsional pada sistem kardiovaskuler. Ketebalan, ukuran ruang ventrikel kiri, berat dan volume jantung akan meningkat pada individu yang terlatih. Alhasil jantung akan memompa darah lebih kuat dan lebih banyak dalam tiap denyutnya. Perubahan denyut jantung akan terlihat sebagai penurunan denyut jantung saat istirahat maupun saat melakukan aktivitas fisik (Fathoni, 2014). Menurut penelitian Andi, dkk (2016) terjadi peningkatan tekanan darah sistolik berkisar $20-60 \mathrm{mmHg}$ sesaat setelah berolahraga futsal. Akan tetapi tekanan darah akan mengalami penurunan sampai dibawah normal dan berlangsung selama 30-120 menit. Penurunan ini terjadi karena pembuluh darah mengalami pelebaran dan relaksasi (Sumosardjono dalam Andi dkk, 2016). Menurut peneliti, seseorang pemain bulutangkis harus memperhatikan frekuensi latihan yang dilakukan, salah satunya yaitu dengan menjaga rutinitas latihan. $\mathrm{Hal}$ ini karena apabila seseorang melakukan latihan dengan frekuensi tidak teratur dan intensitas yang bukan porsinya, maka dapat terjadi ketidakefisiennya suatu latihan dan overtraining pada pemain bulutangkis. Kejadian seperti ini apabila terus menerus 
dilakukan dapat menyebabkan kekakuan pada otot jantung yang dapat meningkatkan risiko terjadinya penyakit jantung seperti hipertensi bahkan serangan jantung yang mengakibatkan kematian. Oleh karena itu tekanan darah sangat perlu dijaga kestabilannya dengan cara menjaga frekuensi dan rutinitas latihan bulutangkis.

\section{KESIMPULAN DAN SARAN}

Hasil penelitian dari 33 responden didapatkan Frekuensi bermain bulutangkis anggota PB UNMUH Ponorogo sebagian besar $(48,5 \%)$ atau 16 orang sebanyak 2 kali seminggu. Tekanan darah anggota $\mathrm{PB}$

UNMUH Ponorogo sejumlah $39,4 \%$ atau 13 responden adalah normal. Terdapat Hubungan

\section{DAFTAR PUSTAKA}

Agustina, S. 2011. Majalah Kesehatan Keluarga Dokter Kita. Jakarta: PT Temprint.

Ardiansyah, M. (2012). Medikal Bedah Untuk Mahasiswa. Yogyakarta: Diva Press.

Guyton. (2007). Buku Ajar Fisiologi Kedokteran. Edisi 11. Jakarta: EGC.

Hernawati. 2008. Sistem Pernafasan Manusia Pada kondisi Latihan Dan Perbedaan Ketinggian. Jakarta: ECG.

Irianto, J.P. (2015).Memahami Berbagai Macam Penyakit. Cetakan Pertama. Bandung : Alfabeta.

Istiyarini, YD., Rosjidi C.H (2008) Aktivitas Fisik Penderita Penyakit Kardiovascular. Karya Tulis IImiah, UNMUH Ponorogo, Tidak dipublikasikan

Kadir, Akmarawita. (2010). ADAPTASI KARDIOVASKULER TERHADAP LATIHAN FISIK. Surabaya: Fakultas Kedokteran Universitas Wijayakusuma Surabaya.

Kemenpora. (2014). Penyajian Data dan Informasi Kepemudaan dan Keolahragaan . Jakarta: Kementrian Pemuda dan Olahraga.

Kozier, \& Erb. (2009). Buku Ajar praktik Keperawatan . Jakarta: EGC.

Kusmana, D., (2006) Olah Raga Untuk Orang Sehat dan Penderita Penyakit Jantung antara Frekuensi Bermain Bulutangkis dengan Kejadian Hipertensi Anggota PB UNMUH Ponorogo dengan $P=0,020(\alpha=0,05)$. Adapun keeratan hubungannya (Value) sebesar 0,452 .

Diharapkan anggota PB UNMUH Ponorogo dapat melakukan latihan bulutangkis secara teratur dan intensitas disesuaikan dengan kemampuannya masing- masing agar mencapai kebugaran optimal dan terhindar dari penyakit hipertensi ataupun penyakit jantung yang lain.Diharapkan penelitian selanjutnya untuk meneliti lebih dalam dengan responden dan waktu yang lebih luas dan banyak agar penelitian lebih representative.

Trias SOK \& senam 10 menit. Jakarta: FK UI.

Nurhidayat, Saiful. 2014. Faktor Risiko Penyakit Kardiovaskuler Pada Remaja $\mathrm{Di} \quad$ Ponorogo. Jurnal Dunia Keperawatan, II (2). pp. 40-47. ISSN 2337-8212

Nursalam. 2003. Konsep dan Penerapan Metodologi Penelitian IImu Keperawatan. Jakarta: Salemba Medika.

Palar, Chrisly M, dkk. (2015). Manfaat Latihan Olahraga Aerobik Terhadap Kebugaran Fisik Manusia. Vol. 3, No. 1. Fakultas Kedokteran Universitas Sam Ratulangi Manado: Manado.

PBSI. (2017). Kejuaraan Bupati Kab. Ponorogo. Ponorogo: Persatuan Bulutangkis Seluruh Indonesia.

Rai, A. (2012). Fitness di Usia 40+. Jakarta: Penerbit Libri.

Sherwood, L. I. (2011). Fisiologi Manusia. Jakarta: EGC.

Sulastri, D., Elmatris, \& Ramadhani, R. (2012). Hubungan Obesitas dengan Kejadian Hipertensi pada Masyarakat Etnik Minangkabau di Kota Padang. Majalah Kedokteran Andalas, 188-201.

Widharto. (2009). Bahaya Hipertensi. Jakarta: Sunda Kelapa Pustaka. 